JURNFL

INOVRSI EKRNOMI

\section{Does intellectual capital of "capital" matter? Investigation of small business revenue}

Siswanti ${ }^{1}$, Syamsul Ridjal $^{2}$, La Ode Sumail ${ }^{3}$

Sekolah Tinggi Ilmu Ekonomi Makassar (STIEM) Bongaya, Indonesia ${ }^{1,2,3}$

Received: 08-08-2021 | Revision: 02-09-2021 | Accepted: 07-09-2021

DOI: 10.22219/jiko.v6i03.18050

\begin{abstract}
The main purpose of this study is to examine the effect of length of business on revenue by mediating financial literacy and moderated by capital management ability. Financial literacy and capital management ability in this paper we call intellectual capital. This study used a saturated sample of 71 respondents. Data were analyzed using descriptive analysis and path analysis. The results of this study show that the length of business has a positive relationship to revenue. Furthermore, in general, knowledge-based intellectual capital has a statistically negative impact on revenue, but this finding is biased. Meanwhile, capital management which is an experience-based intellectual capital has a positive impact on revenue. Last but not least, the moderating variable of the place of business is proven to increase small business revenue.
\end{abstract}

Keywords: Intellectual capital; financial literation; small business

\footnotetext{
1 siswantipmrth@gmail.com

2 ridjalsyamsul@yahoo.com

3 odesumail@stiem-bongaya.ac.id
} 


\section{Introduction}

Financial literacy has a relationship with revenue. Ideally, the better the financial literacy, the higher the revenue (Adi, Zailan, \& Wijiastuti, 2021; Idawati \& Pratama, 2020; Ritonga, Romus, \& Nofianti, 2020; Setiawan, 2020). Financial literacy is also related to business capital management; the better financial literacy, the better managing business capital. Furthermore, good business capital management will encourage revenue (Artaman, Yuliarmi, \& Djayastra, 2015; Marfuah \& Hartiyah, 2019; Nugroho \& Utami, 2020).

The question also arises whether financial literacy grows alone or is influenced by experience, generally measured by small business age. Many studies have examined the effect of business age on financial literacy and financial literacy on revenue, but those that focus on small businesses and emphasize the role of intellectual capital are not often found. This study fills the gap on how intellectual capital as measured by financial literacy and business capital management works to increase revenue. In addition, this study also adds a moderating variable for the location of the business.

\section{Method}

The object of this research is the vegetable small business traders in the Pa'baeng-baeng market, as many as 71 traders with the saturated sample technique. The indicators and research variables can be seen in Table 1. Information was obtained by distributing questionnaires and conducting interviews. The questionnaire was designed based on a Likert scale, namely 1 (strongly disagree) to 5 (strongly agree). The questionnaire has been tested for validity $r>0.30$ and reliability alpha $>0.60$, as Gozali (2014) proposed. Then the existing data is analyzed using path analysis with the help of smart PLS software. The research framework can be seen in Figure 1.

\section{Table 1. Research's indicators and variables}

\begin{tabular}{ll}
\hline \multicolumn{1}{c}{ Variable } & \multicolumn{1}{c}{ Indicator } \\
\hline Variable length of business $(\mathrm{X} 1)$ & Small business's age (yearly) \\
Financial literacy (Y1) & Basic financial literacy; skills and confidence \\
Capital management (Y2) & $\begin{array}{l}\text { Strategy of capital management; level of } \\
\text { experience and confidence }\end{array}$ \\
Business location (Y3) & $\begin{array}{l}\text { In the main aisle or not, represented by } 1 \text { and } \\
\text { Revenue (Y4) }\end{array}$ \\
\hline
\end{tabular}

\section{Empirical Result}

The results of the Kolmogorov-Smirnov test show that the significance value is above alpha 0.05 , so that the data can be said to be normally 
distributed. Then, the tolerance value variable is greater than 0.1 , and the VIF value of all variables is less than 10 . Therefore, it can be stated that there are no symptoms of multicollinearity. Then, the Durbin-Watson test showed that there were no symptoms of autocorrelation. Overall the data meet the classical assumptions so that it is feasible to analyze the data through descriptive analysis and path analysis.

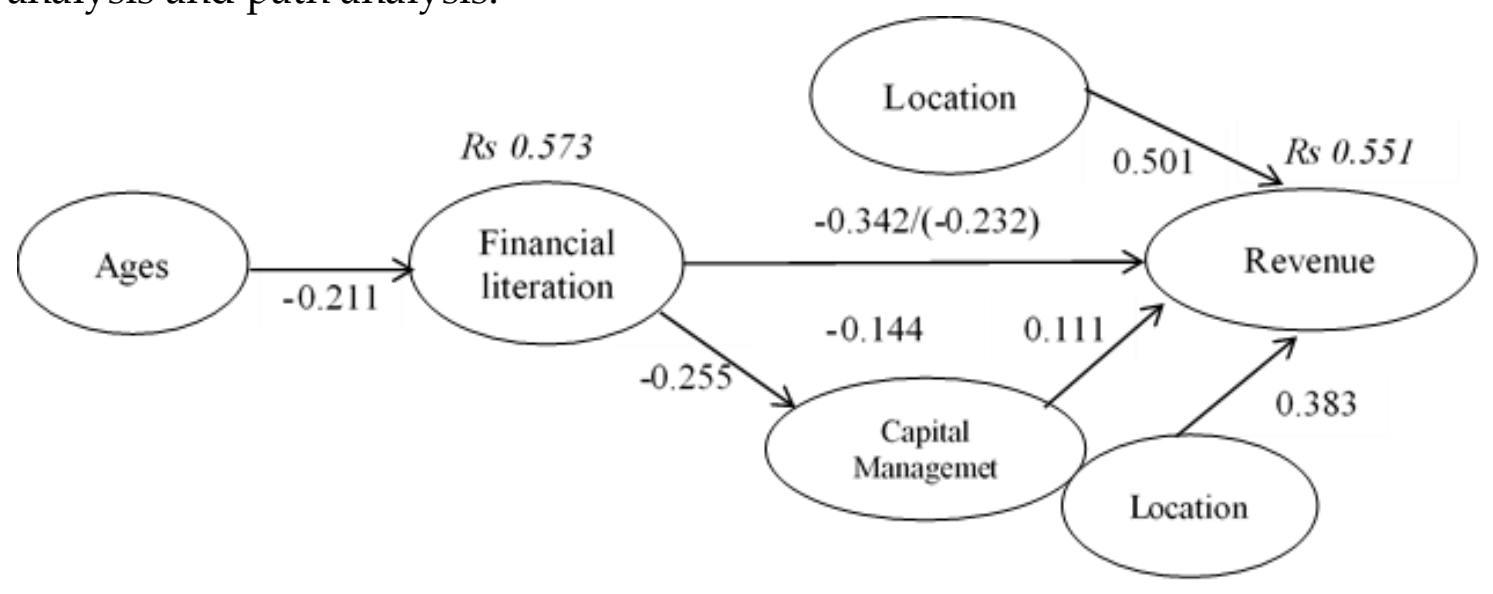

Fig 1. Research framework and results

Small business age with financial literacy has an impact on the revenue of 0.573 or 57.3 percent. The remaining 42.7 percent is explained by variables that are not included in the first model. Then, the second research model is the relationship of financial literacy with revenue mediated by business capital and moderated by business location by 0.551 or 55.1 percent. Meanwhile, the remaining 44.9 percent is explained by other variables. Therefore, both research models can be said to be good and deserve to be analyzed as well as interpreted because the feasibility of the model is above 50 percent (see Fig. 1)

This study found small business age had a negative and significant effect on financial literacy. This means that the longer the business runs, the lower the financial literacy of traders. Furthermore, the study results indicate that financial literacy has a negative and significant effect on the revenue of vegetable traders. Perhaps this result is not reasonable, but seeing the low literacy of our respondents, we suggest an alternative interpretation, namely that financial literacy actually has no effect on revenue, and it is small business age that has a big influence.

This study found that financial literacy has a negative and significant effect on capital management. Once again, this finding is strange, and it is possible that financial literacy here does not influence it. Still, it is small business' age that affects the ability to manage capital. Small business owners in the vegetable sector have high business risks such as easily rotting, wilting, and 
spoiling, so special experience and expertise are needed to manage them. This strange finding regarding financial literacy maybe because most business owners have an elementary school education background, so they do not have the basic financial literacy concepts. Over time, they find a unique way to run their business consistently. This is evident in the relationship between capital management and revenue.

The study results found that capital management has a positive and significant effect on the revenue of vegetable traders. Then, this study shows that without mediation, the coefficient of the relationship between financial literacy and revenue is higher than with mediation. The management of capital can be said to be a partial mediation variable. This finding indicates that the higher capital management leads to higher revenue. This study also found that financial literacy negatively affects revenue mediated by capital management, but the negative relationship is lower. This once again shows that the experience factor in capital management is beneficial for increasing revenue.

Finally, this study also finds that financial literacy positively and significantly affects revenue moderated by business location. The same results for capital management on revenue moderated by business location. That is, the location of the business can increase revenue. So as long as the estimated cost of renting a more strategic location can be covered with potential revenue, small business actors should also consider relocating places.

\section{Conclusions}

The findings of this study indicate that the role of intellectual capital, which consists of financial literacy and capital management, does not fully affect revenue. Knowledge-based intellectual capital, namely financial literacy, in general, hurts revenue; this result is certainly biased because it is possible that it is not low financial literacy but small business' age that has a significant positive effect on revenue. However, experience-based intellectual capital, namely capital management in general, has a positive impact on revenue. This is even strengthened when capital management mediates financial literacy; the negative impact of financial literacy is not as large as in conditions without mediation. Finally, this study shows that the moderating factor that greatly influences revenue is the strategic location of the business.

\section{References}

Adi, J. M., Zailan, A., \& Wijiastuti, S. (2021). Analisis Tingkat Literasi Keuangan (Pengetahuan Keuangan, Sikap Keuangan, Dan Kesadaran Keuangan) Terhadap Kinerja Usaha Kecil (Studi Kasus di Kalurahan Sumberejo Kecamatan Jatisrono Kabupaten Wonogiri). Jurnal Widya Ganecwara, 11(1), $1-10$. 
Artaman, D. M. A., Yuliarmi, N. N., \& Djayastra, I. K. (2015). Analisis FaktorFaktor Yang Mempengaruhi Pendapatan Pedagang Pasar Seni Sukawati Gianyar. E-Jurnal Ekonomi Dan Bisnis Universitas Udayana, 02(xxx), 87-105.

Aulia Inderianti, R., Hardiani, H., \& Rosmeli, R. (2020). Analisis faktor-faktor yang mempengaruhi pendapatan pedagang kaki lima di Kota Jambi (studi kasus warung manisan Kecamatan Telanaipura). E-Jurnal Perspektif Ekonomi Dan Pembangunan Daerah, 9(3), 109-118.

Christoper, S. W. H., \& Kristianti, I. (2020). Hubungan E-Commerce Dan Literasi Keuangan Terhadap Kelangsungan Usaha Di Boyolali. Jurnal Akuntansi, 10(1), 1-12.

Fitriyani, S., Murni, T., \& Warsono, S. (2019). Pemilihan Lokasi Usaha Dan Pengaruhnya Terhadap Keberhasilan Usaha Jasa Berskala Mikro Dan Kecil. Managament Insight: Jurnal Ilmiah Manajemen, 13(1), 47-58.

Gozali, Imam. (2014) Ekonometrika: Teori, Konsep dan Aplikasi dengan IBM SPSS 22, Badan Penerbit Universitas Diponegoro, Semarang.

Hidayat, R. T., \& Zuliarni, S. (2014). Pengaruh Lokasi Usaha Pada Volume Penjualan (Survei pada Restoran Kecil di Lingkungan Universitas Riau). Jurnal Ilmiah Akuntansi Dan Bisnis, 9(2), 92-100.

Hilmawati, M. R. N., \& Kusumaningtias, R. (2021). Inklusi Keuangan Dan Literasi Keuangan Terhadap Kinerja Dan Keberlangsungan Sektor Usaha Mikro Kecil Menengah. Nominal: Barometer Riset Akuntansi Dan Manajemen, 10(1), 135-152.

Husaini, A. F. (2017). Pengaruh Modal Kerja , Lama Usaha , Jam Kerja dan Lokasi Usaha terhadap Pendapatan Monza di Pasar Simalingkar Medan. Jurnal Visioner E Strategis, 6(2), 3-13.

Idawati, I. A. A., \& Pratama, I. G. S. (2020). Pengaruh Literasi Keuangan Terhadap Kinerja dan Keberlangsungan UMKM di Kota Denpasar. Warmadewa Management and Business Journal (WMBJ), 2(1), 1-9.

Indrayani, L. (2020). Makna Literasi Keuangan dalam Keberlangsungan Usaha Industri Rumah Tangga Perempuan Bali. JIA (Jurnal Ilmiah Akuntansi), 5(2), $407-428$.

Latifiana, D. (2017). Studi Literasi Keuangan Pengelola Usaha Kecil Menengah ( Ukm ). Studi Literasi Keuangan Pengelola Usaha Kecil Menengah (UMKM), Junal Manajemen 5(1), 5.

Marfuah, S. T., \& Hartiyah, S. (2019). Pengaruh Modal Sendiri, Kredit Usaha Rakyat (KUR), Teknologi, Lama Usaha, dan Lokasi Usaha terhadap Pendapatan Usaha. Journal of Economic, 1(1), 183-195.

Ningtyas, M. N., \& Andarsari, P. R. (2021). Peran Perilaku Keuangan dalam Memoderasi Literasi Keuangan dan Keberlangsungan Usaha. Jurnal Riset Dan Aplikasi: Akuntansi Dan Manajemen, 5(1), 37-44. 
Nugroho, N. T., \& Utami, I. W. (2020). Pengaruh Modal, Lokasi Usaha, Dan Kondisi Tempat Berdagang Terhadap Pendapatan Pedagang (Study Kasus Pada Pasar Kartasura Kabupaten Sukoharjo). Jurnal Manajemen, Bisnis Dan Pendidikan, 7(1), 69-75.

Prakoso, a. (2020). Pengaruh Literasi Keuangan terhadap Kinerja UMKM se-Eks Karesidenan Besuki Jawa Timur. VALID Jurnal Ilmiah, 17(2), 151-161.

Pramestiningrum, D. R., \& Iramani, I. (2020). Pengaruh literasi keuangan, financial capital, kebijakan pemerintah terhadap kinerja usaha pada usaha kecil dan menengah di Jawa Timur. Journal of Business and Banking, 9(2), 279.

Putri, W. E. (2020). Pengaruh Literasi Keuangan Terhadap Pengelolaan Keuangan UMKM. Jurnal Pembangunan Perkotaan, 8(1), 45-50.

Ritonga, A., Romus, M., \& Nofianti, L. (2020). Analisis Tingkat Literasi Keuangan Syariah dan Dampaknya Terhadap Pendapatan Usaha Mikro di Kecamatan Siak Hulu Kabupaten Kampar. Jurnal Pemberdayaan Masyarakat, $8(1), 1$.

Setiawan, B. (2020). Literasi Keuangan Pelaku Usaha Mikro, Kecil Dan Menengah (Umkm) Kota Palembang. Jurnal Abdimas Mandiri, 4(02), 70-75.

Wahyu Rumbianingrum, \& Wijayangka, C. (2018). Pengaruh Literasi Keuangan Terhadap Pengelolaan Keuangan Umkm. Jurnal Manajemen Dan Bisnis (ALMANA), 2(3), 155-165. 